\title{
Range condition, tenure, management, and bio-phyiscal relationships in Sonora, Mexico
}

\author{
JOSE A. CORONADO-QUINTANA AND MITCHEL P. MCCLARAN
}

Authors are professor of Management, University of Sonora, Reforma y Colosio, Hermosillo, Son., México 83100 and associate professor of Range Management, University of Arizona, Tucson, Ariz. USA 85721.

Abstract

The objective of this study was to describe the relationship among range condition scores, tenure system, management practices and bio-physical variables for 107 communal ejido ranches and 373 private ranches in Sonora, Mexico. The data was obtained from assessments of range condition and recommended carrying capacity for individual ranch units that were completed between 1973 and 1993 by the Comisión Técnica para la Determinación de Coeficientes de Agostadero. Variables measured were range condition, land tenure (communal ejido or private ranch), management characteristics (human density, livestock stocking rate, ranch size, and infrastructure condition), and bio-physical characteristics (rangeland site quality and precipitation in the year of assessment). We used a combination of simple, univariate chi-square analyses and more complex, multivariate ordered logistic regression analyses to assess the relationships among these variables. There was no evidence from the logistic regression analysis that range condition of ranches in Sonora was related to the ejido or private tenure systems. Infrastructure condition was different between the 2 tenure systems, and infrastructure condition was positively related to range condition for both ejido and private ranches. Based on the univariate and multivariate analyses, precipitation amounts in the year of assessment was less for private ranches, and range condition on private ranches was more sensitive to precipitation than ejido ranches. Compared to estimates made in the 1960's and 1970's in other parts of Mexico, we found there to be less of a difference in stocking rate between the more lightly stocked private ranches and more heavily stocked ejido ranches, and generally good condition infrastructure on all ranches. The important relationship between precipitation and range condition implies that range condition assessments should be done over many years to produce estimates of trend that can be compared across wet and dry years.

Key Words: communal resources, ejido, infrastructure, precipitation

The relationship between rangeland conditions and land tenure systems, particularly private versus non-private tenure systems, has long been viewed as a basic element in the management of rangeland uses (e.g. Smith 1898, Worster 1992). The articulation

Special thanks are given to Dr. David King and Dr. Lamar Smith from the University of Arizona for their advice and to the Consejo Nacional de Ciencia y Tecnología (CONACYT) for its financial support to complete this research project. Manuscript accepted 25 Apr. 2000.

\section{Resumen}

El objetivo de este estudio fue describir la relación entre condición del pastizal y el sistema de tenencia de la tierra, variables biof'sicas y de manejo de 107 ejidos y 373 propiedades privadas. Los datos fueron obtenidos de los estudios de condición y determinación de carga animal realizados de 1978 a 1993 en el estado de Sonora, México por la Comisión Técnica para la Determinación de Coeficientes de Agostadero. Las variables consideradas fueron condición del pastizal, tipo de propiedad (ejido ó propiedad privada), caracter'sticas de manejo (densidad humana, carga animal, tamaño de la unidad y condición de la infraestructura), y variables biofísicas (calidad del pastizal y precipitación durante el año de estudio). La información fue analizada usando tabulaciones simples y modelos de regresión logística en la bísqueda de relaciones entre las variables. Mediante regresión log'stica, no se encontró relación entre condición y tenencia de la tierra. La condición de la infraestructura fue diferente entre ambos tipos de propiedad y positivamente relacionado con la condición del pastizal. En base a la tabulación y regresión logística, la cantidad de precipitación durante los años de estudio fue menor para las propiedades privadas y, la condición de los pastizales en las propiedades privadas fue mas sensible a la precipitación que en los ejidos. Comparado con estudios hechos en los 1960's y 1970's, en otras partes del país, se encontró menos diferencia entre carga animal aplicada en los ejidos y las propiedades privadas y en general, mejor infraestructura en ambos tipos de propiedad. La relación importante entre condición del pastizal y precipitación, indica que los estudios de evaluación de condición de los pastizales deben hacerse durante muchos años para poder obtener estimaciones de tendencias que permitan hacer comparaciones entre años de baja y alta precipitación.

of this relationship for Mexican rangelands became more important after 1991, when amendments to article 27 of the Mexican Constitution permitted the alienation (sale of property rights) of communal lands known as ejidos with the goal of improving the productive output of these lands (Solidaridad 1992). In this paper, we evaluate the relationships among land tenure system (private vs. ejido), rangeland conditions, management practices (e.g. stocking rate and infrastructure conditions) and bio-physical rangeland characteristics (e.g. rangeland site quality and precipitation) in the state of Sonora, Mexico.

Since Hardin's (1968) Tragedy of the Commons publication, various non-private tenure systems have been characterized according to rules governing access to resources (Ostrom et al. 1999). For example, Hardin (1968) described an open-access 
communal system where individuals' unlimited access to pasture resources resulted in a decline in the productive condition of the pasture. In contrast, limitedaccess communal systems use cultural norms and social systems to establish rules for the individual's access to resources while maintaining a non-private property rights tenure system (e.g. Feeny et al. 1990). Beyond the access-exclusion contrasts, there are different expectations concerning the willingness to invest in resource management among tenure systems. Some argue that market forces will act to foster greater investment under private ownership (e.g. Baden and Stroup 1977). In contrast, Wilson and Thompson (1993) found that limited-access ejido communal systems in the Northern Altiplano of Mexico were better able to withstand the risks of rangeland livestock production if costs of enforcing limited access were not prohibitive, and if human and financial capital were available to perform sustainable management practices.

In the context of tenure systems, we ask if different levels of management are observed across tenure systems, and whether these differences are manifest as differences in the condition of resources. A basic tenet of rangeland management is that management practices will influence resource condition, and therefore, we expect a negative relationship between grazing intensity (i.e. stocking rate) and resource conditions (albeit, not necessarily a linear relationship; e.g. Hart et al. 1993), and we expect the development of fence and water infrastructure to foster an improvement of rangeland conditions (e.g. Vallentine 1990). An alternative hypothesis is that differences in management practices transcend tenure systems, and, therefore, resource conditions are more strongly related to management than tenure system.

We ask if there is a consistent pattern in the inherent quality of rangeland sites according to land tenure system, and whether these differences are manifest as differences in rangeland condition. For example, the role of bio-physical characteristics in determining a potential for rangeland condition is expressed through the classification of rangeland sites (ecological sites) that vary in their soils, climate, vegetation and primary productivity (Humphrey 1949, Anderson and Fly 1955), and therefore, different rangeland sites may possess different potentials to respond to management practices (e.g. Launchbaugh et. al. 1990). The distribution of different range sites may vary among land tenure systems (e.g. Loring and Workman 1987), and such variation could account for some of the variation in resource condition among tenure systems. We ask if there is a relationship between tenure systems and the amount of precipitation occurring during the year of the condition assessment, and if these differences are manifest as differences in the condition of resources. Assessing the role of management on rangeland conditions is contingent on a rating system where the influences of management are independent of (or at least distinguishable from) other factors such as precipitation. In fact, precipitation pattern has been specified as an explicit agent of transition in the stateand-transition model (Westoby et al. 1989), and precipitation is considered a primary driving force in the abundance of vegetation in arid ecosystems (Ellis and Swift 1988). Therefore, our analysis of the role of precipitation addresses fundamental issues concerning the utility of the rangeland condition metric in identifying the agents responsible for different resource conditions.

Our objective is to inform the debate on the role of tenure systems in determining rangeland conditions by describing for 480 ranches in Sonora, Mexico the relationship among rangeland condition scores measured from 1973 to 1993 , tenure system, management practices and bio-physical variables.

\section{Methods}

\section{Study Area}

Since the Mexican Revolution of 1910, the term ejido has been applied to all types of land distributed to groups of 20 or more persons (Coronado-Quintana 1998). Ejido is a type of land tenure where property rights are assigned to the group, each group member enjoys the right to use a specific resource, and that use is regulated by rules imposed by the property right holders and government authorities. With amendments in 1991 to article 27 of the Mexican Constitution that permitted alienation of property rights, the government intended to eliminate paternalism and increase flexibility in order to improve the ability of the ejido to meet changing economic conditions (Solidaridad 1992).

In 1988, there were 95.1 million hectares of ejidal land in Mexico (49 percent of the land area), which was distributed among 28,058 ejidos and agrarian communities and 3,070,906 ejidatarios (Instituto Nacional de Estadistica, Geografia y Informatica 1990). The majority of these lands are rangelands
(54.2 million ha) dedicated to the production of livestock. Located in northwestern Mexico, the state of Sonora covers 18.5 million ha, with nearly $91 \%$ of the land area used for livestock production. Ejidal land covers 5.2 million ha $(28 \%$ of the area) and is distributed among 889 communal ejidos, of which 594 are engaged in some kind of livestock production (Instituto Nacional de Estadistica, Geografia y Informatica 1994). These livestock producing ejidos accounted for nearly $12 \%$ of the 5,188 properties producing livestock in Sonora (Instituto Nacional de Estadistica, Geografia y Informatica 1997).

\section{Data}

The data for this study was obtained from assessment of range condition and recommended carrying capacity for individual ranch units completed by the Comisión Técnica para la Determinación de Coeficientes de Agostadero (COTECOCA) from 1973 to 1993 . The full data set described 739 ranches, including ejidos, Indian communities, and private properties. However, due to missing variables for some ranches in the data set, our analysis used only the 480 ranches without missing data.

For the purpose of this study, a ranch unit is a piece of land managed by an individual (normally private properties) or a group of individuals (ejidos or Indian communities) in a contiguous geographic area. If more than 1 property was managed by a single individual or ejido, the 2 or more properties were treated as separate ranches if they were located in different areas of Sonora.

A total of 107 ejido ranches were included in the sample of 480 ranches. These ejidos represent $26 \%$ of the ranches and $58 \%$ of the land in the 480 ranch sample. These proportions are about twice as high as the representation of ejidos ranches and land area in Sonora, as described above. However, given the total sample size, this over-representation should not adversely influence our analysis of the relationships among range condition, tenure system, management practices, and bio-physical resources for these ranches.

In our analysis, we used COTECOCA measurements of range condition, land tenure, management characteristics (human density, livestock stocking rate, ranch size, and infrastructure condition), and bio-physical characteristics (rangeland site quality and precipitation).

\section{Range Condition}

The COTECOCA used a modified climax plant community approach (Dyksterhuis 1949) to estimate range condition, where 
plant cover (basal cover for grasses and herbs and foliar cover for shrubs and trees) was measured as the vegetation parameter. Most COTECOCA studies used the Canfield Line Intercept or Step Point methods to estimate plant cover (Evans and Love 1957). As modified by COTECOCA, the condition rating was biased toward plants contributing to livestock diets and production, and therefore, if a rating was excellent, it did not necessarily equate to a climax composition. Furthermore, range condition rating was lowered if there were signs of accelerated erosion.

The COTECOCA studies determined range condition for each range site (ecological site) on each ranch unit. Four range condition categories were used to organize the condition ratings based on the proportion of plant cover measured for excellent species: greater than $75 \%$ cover contributed by excellent species equated to excellent condition, 51 to $75 \%$ equated to good condition, 25 to $50 \%$ equated to regular condition, and less than $25 \%$ equated to poor condition (Comisión Técnica para la Determinación de Coeficientes de Agostadero 1974).

We developed a composite range condition score for each ranch unit by calculating a weighted average according to the proportion of the property covered by each range site,

$$
\begin{aligned}
& \sum\left(\text { condition score }_{i} \times \text { hectares }_{i}\right) / \text { total } \\
& \text { ranch hectares }
\end{aligned}
$$

where condition scores were 1, 2, 3, and 4 for poor, regular, good and excellent condition, respectively, and the subscript $i$ designates the area of each range site found on the ranch unit. A ranch unit with a weighted average of 1 through 1.49 was classified in poor condition, a 1.5 through 2.49 weighted average was classified in regular condition, a 2.5 through 3.49 weighted average was classified in good condition, and a weighted average greater than 3.49 was classified in excellent condition. Because only 4 ranch units were in excellent condition, they were grouped with those found to be in good condition.

\section{Land Tenure}

Land tenure was represented as a dummy variable with a value of 0 if the ranch was ejido or Indian community property and a value of 1 if the ranch was private property. In the original sample, ejidos and Indian communities were described as separate categories, but because the Indian community properties were few and were managed in the same manner as ejidos, they were grouped as one type of property called ejido.

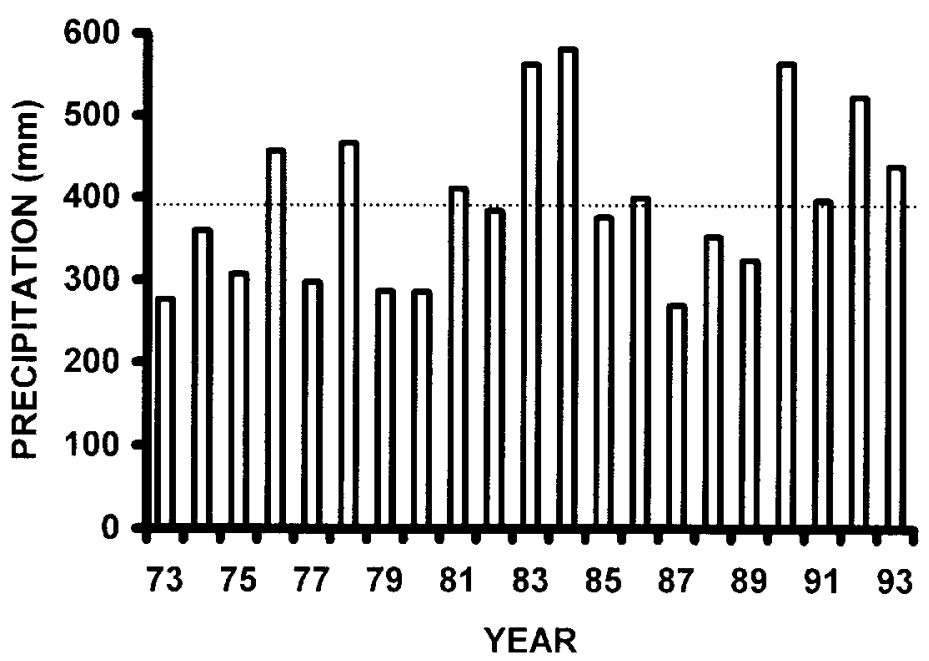

Fig. 1. Annual (bars) and average (dotted line) precipitation for Sonora, Mexico, 1973-1993.

\section{Management Characteristics}

Human density is the number of hectares per property right holder (hectares/person). A property right holder was considered a person who had a legal right to use the land. Normally, and according to the law, ejidos have a minimum of 20 members. Most of the private properties have just 1 legal owner.

The COTECOCA estimated the livestock stocking rate as the normal number of animal units per hectare grazing on the ranch unit during an entire calendar year, based on forage samples and complimentary information from ranchers and previous ranch studies (Comisión Técnica para la Determinación de Coeficientes de Agostadero 1974).

Ranch unit size was measured in hectares; excluding irrigated and cultivated pastures, cropping areas, and places considered unsuitable for livestock grazing. In the establishment of ranch size for ejidos, we ignored the presence of any internal subdivisions that ejidatarios may have made to divide a pasture.

The COTECOCA personnel used 3 categories (poor, regular, and good) to describe the condition of livestock management infrastructure (e.g. fences, corrals, and watering places) for the entire ranch unit. We coded the condition classes as $1=$ poor, 2 = regular, and $3=$ good.

\section{Bio-physical Characteristics}

The COTECOCA applied the range site concept (Anderson and Fly 1955) to distinguish 4 classes of rangeland quality based on the potential for biomass production. These classes recognize that the productivity potential of a range site is a function of soil, slope, climate and potential vegetation.
Similar to the composite range condition score, we also calculated a composite rangeland site quality score for each ranch unit by calculating a weighted average according to the proportion of the property covered by each of 4 site quality classes established by COTECOCA. Site quality scores were 1, 2, 3, and 4 for poor, regular, good and excellent quality, respectively. A ranch unit with a weighted average of 1 through 1.49 was classified as poor quality, a 1.5 through 2.49 weighted average was classified as regular quality, a 2.5 through 3.49 weighted average was classified as good quality, and a weighted average greater than 3.49 was classified as excellent quality. Because only 24 ranch units were in the excellent quality category, they were grouped with those found to be in the good quality category.

The amount for precipitation associated with each ranch unit was based on the average precipitation in Sonora during the year that the range condition survey was completed by COTECOCA (Fig. 1). The weighted average precipitation value was estimated by Comisión Nacional del Agua for the State of Sonora (1996), where precipitation readings are obtained from different points in 7 watersheds, and then the average of the records from the 7 watersheds represents the precipitation for the State in a given year.

\section{Data Analysis}

We used a combination of simple, univariate chi-square contingency analyses and more complex, multivariate ordered logistic regression analyses to assess the relationship among the variables. The chisquare analysis provides a clear presentation of the actual values of the parameters 
and is easily understood, but this approach does not assess the strength of relationships between more than 2 variables at a time. The logistic regression describes the relative strengths of the relationship of all the independent variables with the dependent variable simultaneously, but it is difficult to visualize the distribution of the actual values of these variables because of the logistic transformation. Finally, chisquare analysis was used to express the actual values for some variables found to have significant relationships in the multivariate analyses.

The univariate approach used the chisquare method (Kohler 1988) to evaluate differences in the distribution of range condition, management variables, and biophysical variables between land tenure systems and among range condition classes. The multivariate approach used the ordered logistic regression method (Hosmer and Lemeshow 1989, Greene 1993) to compare the relative importance of independent variables in distinguishing among classes of land tenure system (ejido and private) and among ordered classes of range condition (poor, regular, and good).

To distinguish between ejido and private ranches, we used an analysis where the dependent variables were ejido and private ranches and the independent variables were the categorical variables of infrastructure condition and range quality, and the continuous variables of range condition, hectares per person, hectares per animal unit, and precipitation. Ranch size was not included in this analysis because it was greatly different between tenure types and thus other independent variables would not be needed to differentiate between ejido and private ranches.

To distinguish among the ordered categories of poor, regular and good range condition, we performed 3 separate regression analyses. The first analysis used all ranches and all independent variables were included (categorical variables were tenure system, infrastructure condition, and range quality, and the continuous variables were ranch size, hectares per person, hectares per animal unit and precipitation). The second and third regression analyses were restricted to ranches in each tenure category: ejido only or private only. The comparison between these 2 restricted analyses provides a simple assessment of the interaction between tenure system and the other independent variables.

Ordered logistic regression is a better framework to analyze ordinal dependent variables like land tenure and range condition than using linear regression. With ordinal dependent variables, it is unlikely that the linear regression assumption of normally distributed errors will be met, and the coefficients can not be interpreted as probabilities for classifying cases into the ordinal categories. In contrast, the ordered logistic regression method calculates coefficients that can be interpreted as the odds ratio that there will be a change in the dependent variable category with a change in the independent variable. For example, if we find a negative coefficient for the independent variable of ranch size in relation to land tenure $(0=$ ejido and $1=$ private), then we interpret this to mean that it is less likely that a ranch will be privately owned as ranch size increases. If the coefficient is positive, then it is more likely

Table 1. Distribution of management characteristics (human density, stocking rate, ranch size, and infrastructure condition) and bio-physical characteristics (range site quality and precipitation) within categories of property type and range condition rating. Probabilities ( $p$ values) represent chi-square probabilities that there is no difference in the distribution of the proportions between property types or among range condition classes.

\begin{tabular}{|c|c|c|c|c|c|}
\hline & \multicolumn{2}{|c|}{$\begin{array}{c}\text { Property Type } \\
\text { (percent of ranches) }\end{array}$} & \multicolumn{3}{|c|}{$\begin{array}{c}\text { Range Condition Rating } \\
\text { (percent of ranches) } \\
\end{array}$} \\
\hline & $\begin{array}{c}\text { Ejido } \\
(\mathrm{n}=107)\end{array}$ & $\begin{array}{l}\text { Private } \\
(\mathrm{n}=373)\end{array}$ & $\begin{array}{c}\text { Poor } \\
(n=153)\end{array}$ & $\begin{array}{l}\text { Regular } \\
(\mathrm{n}=249)\end{array}$ & $\begin{array}{l}\text { Good } \\
(n=78)\end{array}$ \\
\hline $\begin{array}{l}\text { Range Condition } \\
\text { Ejido } \\
\text { Private }\end{array}$ & $-\cdots-\cdots$ & - - - -- -- & $\begin{array}{c}---- \\
16.8 \\
36.2\end{array}$ & $\begin{array}{c}-(\%)--- \\
78.5 \\
44.2 \\
p<0.001\end{array}$ & $\begin{array}{c}-7 \\
4.7 \\
19.6\end{array}$ \\
\hline $\begin{array}{l}\text { Human Density (ha/person) } \\
\leq 100 \\
>100 \text { to } \leq 500 \\
>500 \text { to } \leq 1000 \\
>1000 \text { to } \leq 2000 \\
>2000 \text { to } \leq 3000 \\
>3000\end{array}$ & $\begin{array}{r}66.4 \\
29.9 \\
3.7 \\
0.0 \\
0.0 \\
0.0\end{array}$ & $\begin{array}{r}1.6 \\
13.7 \\
27.1 \\
25.5 \\
15.0 \\
17.2 \\
1\end{array}$ & $\begin{array}{r}10.5 \\
22.9 \\
22.2 \\
22.2 \\
9.2 \\
12.4\end{array}$ & $\begin{array}{c}22.5 \\
15.3 \\
20.1 \\
17.7 \\
11.2 \\
13.3 \\
\mathrm{p}=0.006\end{array}$ & $\begin{array}{r}6.4 \\
12.8 \\
26.9 \\
20.5 \\
17.9 \\
15.4\end{array}$ \\
\hline $\begin{array}{l}\text { Stocking Rate (ha/AU) } \\
<6 \\
>6 \text { to } \leq 12 \\
>12 \text { to } \leq 18 \\
>18\end{array}$ & $\begin{array}{l}29.9 \\
43.9 \\
15.0 \\
11.2\end{array}$ & $\begin{array}{r}16.6 \\
52.8 \\
17.7 \\
12.9 \\
1\end{array}$ & $\begin{array}{l}22.8 \\
51.0 \\
13.7 \\
12.4\end{array}$ & $\begin{array}{c}20.5 \\
45.8 \\
20.9 \\
12.9 \\
\mathrm{p}=0.03\end{array}$ & $\begin{array}{l}10.3 \\
66.7 \\
11.5 \\
11.5\end{array}$ \\
\hline $\begin{array}{l}\text { Ranch Size (ha) } \\
<1000 \\
>1000 \text { to } \leq 2000 \\
>2000 \text { to } \leq 3000 \\
>3000 \text { to } \leq 4000 \\
>4000\end{array}$ & $\begin{array}{r}7.5 \\
10.3 \\
13.1 \\
13.1 \\
56.1\end{array}$ & $\begin{array}{r}41.8 \\
25.7 \\
15.3 \\
7.5 \\
9.7 \\
\end{array}$ & $\begin{array}{r}44.4 \\
24.8 \\
11.1 \\
5.9 \\
13.7\end{array}$ & $\begin{array}{c}26.1 \\
20.5 \\
15.3 \\
12.0 \\
26.1 \\
\mathrm{p}=0.001\end{array}$ & $\begin{array}{r}39.7 \\
23.1 \\
20.5 \\
3.8 \\
12.8\end{array}$ \\
\hline $\begin{array}{l}\text { Infrastructure Condition } \\
\text { Poor } \\
\text { Regular } \\
\text { Good }\end{array}$ & $\begin{array}{l}18.7 \\
62.6 \\
18.7\end{array}$ & $\begin{array}{r}7.2 \\
48.8 \\
44.0 \\
\end{array}$ & $\begin{array}{l}13.7 \\
57.5 \\
28.8\end{array}$ & $\begin{array}{c}8.4 \\
54.2 \\
37.4 \\
\mathrm{p}=0.001\end{array}$ & $\begin{array}{r}6.4 \\
33.3 \\
60.3\end{array}$ \\
\hline $\begin{array}{l}\text { Range Site Quality } \\
\text { Poor } \\
\text { Regular } \\
\text { Good } \\
\text { Excellent }\end{array}$ & $\begin{array}{r}14.0 \\
55.1 \\
28.0 \\
2.8\end{array}$ & $\begin{array}{r}19.3 \\
44.5 \\
30.6 \\
5.6\end{array}$ & $\begin{array}{r}30.1 \\
29.4 \\
33.3 \\
7.2\end{array}$ & $\begin{array}{c}14.1 \\
54.2 \\
28.1 \\
3.6 \\
\mathrm{p}=0.001\end{array}$ & $\begin{array}{r}7.7 \\
57.7 \\
29.5 \\
5.1\end{array}$ \\
\hline $\begin{array}{l}\text { Precipitation }(\mathrm{mm}) \\
<287 \\
287-376 \\
377-409 \\
>409\end{array}$ & $\begin{array}{r}17.8 \\
7.5 \\
22.4 \\
52.3\end{array}$ & $\begin{array}{r}31.4 \\
28.1 \\
22.0 \\
18.5 \\
1\end{array}$ & $\begin{array}{r}39.2 \\
40.5 \\
12.4 \\
7.9\end{array}$ & $\begin{array}{c}20.5 \\
16.5 \\
27.7 \\
35.3 \\
\mathrm{p}=0.001\end{array}$ & $\begin{array}{l}32.1 \\
12.8 \\
23.0 \\
32.1\end{array}$ \\
\hline
\end{tabular}


Table 2. Coefficients, $z$-scores, and probabilities ( $p$ values) for the logistic regression analysis to distinguish ejido and private Sonoran ranches.

\begin{tabular}{lccc}
\hline \hline Independent Variable & Coefficient & $\mathrm{z}-$ score & $\mathrm{p}>|\mathrm{z}|$ \\
\hline Range Condition & -0.25 & -0.62 & 0.54 \\
Human Density & 0.01 & 7.38 & $<0.01$ \\
Livestock Stocking Rate & 1.47 & 2.69 & $<0.01$ \\
Poor Infrastructure & -0.44 & 0.53 & 0.59 \\
Regular Infrastructure & 0.37 & 0.65 & 0.52 \\
Poor Rangeland Quality & -0.11 & -0.15 & 0.88 \\
Regular Rangeland Quality & -0.78 & -1.41 & 0.16 \\
Precipitation & -0.01 & -4.23 & $<0.01$ \\
\hline
\end{tabular}

revealing a greater proportion of private ranch units with good and poor condition ratings than ejido ranch units (Table 1).

The distribution of ranch units in the 2 property type categories was different for all the management and bio-physical variables except range site quality (Table 1), revealing respectively, a) a higher proportion of ejido ranches with the fewest hectares per person, b) a higher proportion of ejido ranches with the fewest hectares per animal unit (i.e. higher stocking rate), c) a higher proportion of ejido ranches in the largest ranch size category, d) a higher proportion of private ranches in the good infrastructure category, and e) a greater proportion of ejido ranches in the highest precipitation category.

The distribution of ranch units in the 3 range condition categories was different for all management and bio-physical variables (Table 1), revealing respectively a) a higher proportion of regular condition ranches with the fewest hectares person, b) a lower proportion of good condition ranches with the fewest hectares per animal unit (i.e. higher stocking rate), c) a lower proportion of regular condition ranches in the smallest sizes classes, d) a greater proportion of good condition ranches with good infrastructure, e) a lower proportion of poor range condition ranches in the highest site quality category, and $f$ ) a lower proportion of poor condition ranches received the highest amount of precipitation.

Only human density, livestock stocking rate, and precipitation were significantly related to land tenure system (ejido or private) in the logistic regression analysis (Table 2). The results accounted for a large portion of the variability between tenure system types (pseudo $\mathrm{r}^{2}=0.77$ ). The direction (+ or - ) of the coefficients show that hectares per human and hectares per animal unit were greater for private ranches, but precipitation during the assessment was greater for ejido ranches.

Only infrastructure condition, range quality and precipitation were significantly related to range condition in the analy- sis that included all ranches (Table 3 ). These independent variables accounted for a small, but significant portion of the variability among range condition categories (pseudo $\left.\mathrm{r}^{2}=0.11\right)$. The direction $(+$ or - ) of the coefficients show that a) ranches with regular and good range condition ratings were more likely to have received higher precipitation amounts, b) ranches in good condition were less likely to have poor than regular or good condition infrastructure, and c) ranches in good condition were more likely to have regular rangeland quality. For ejido ranches only, the distinction among ranches in the 3 categories of range condition was slightly better than the analysis with all ranches (pseudo $r^{2}=0.17$ ), and only infrastructure condition was significantly related to

Table 3. Coefficients, $z$-scores, and probabilities (p values) for the ordered logistic regression analyses for all ranches, ejido ranches only, and private ranches only to distinguish Sonoran ranches in poor, regular, and good range condition.

\begin{tabular}{lrrr}
\hline \hline Independent Variable & Coefficient & z-score & $\mathrm{p}>|\mathrm{z}|$ \\
\hline All Ranches & -0.16 & -0.52 & 0.60 \\
Tenure System & $<0.01$ & 1.21 & 0.23 \\
Human Density & 0.03 & 0.07 & 0.95 \\
Livestock Stocking Rate & -0.01 & -1.95 & 0.05 \\
Ranch Size & -1.35 & -3.88 & $<0.01$ \\
Poor Infrastructure & -1.03 & -4.88 & $<0.01$ \\
Regular Infrastructure & -0.52 & -1.92 & 0.06 \\
Poor Rangeland Quality & 0.49 & 2.36 & 0.02 \\
Regular Rangeland Quality & $<0.01$ & 6.50 & $<0.01$ \\
Precipitation & & & \\
Ejido Ranches Only & $>-0.01$ & -0.51 & 0.61 \\
Human Density & -0.37 & -0.47 & 0.64 \\
Livestock Stocking Rate & -0.01 & -1.76 & 0.08 \\
Ranch Size & -2.37 & -2.54 & 0.01 \\
Poor Infrastructure & -0.08 & -0.11 & 0.92 \\
Regular Infrastructure & 0.31 & 0.38 & 0.70 \\
Poor Rangeland Quality & 0.85 & 1.41 & 0.16 \\
Regular Rangeland Quality & $<0.01$ & 1.87 & 0.06 \\
Precipitation & & & \\
Private Ranches Only & $<0.01$ & 1.34 & 0.18 \\
Human Density & 0.57 & 0.92 & 0.36 \\
Livestock Stocking Rate & -0.01 & -1.31 & 0.19 \\
Ranch Size & -0.94 & -2.25 & 0.03 \\
Poor Infrastructure & -1.20 & -5.24 & $<0.01$ \\
Regular Infrastructure & -1.93 & 0.05 \\
Poor Rangeland Quality & -0.59 & 1.86 & 0.06 \\
Regular Rangeland Quality & 0.43 & & 0.01 \\
Precipitation & $<0.01$ & & \\
\hline & & & \\
\hline & & & \\
\hline
\end{tabular}
ment, and the proportion of ejido ranches range condition; where the proportion of ranches in poor condition was greater for poor infrastructure than good or regular infrastructure (Table 3). In the analysis for private ranches only, the distinction among ranches in the 3 categories of range condition was nearly the same as the analysis with all ranches (pseudo $\mathrm{r}^{2}=$ 0.13 ), and only infrastructure condition and precipitation were significantly related to range condition; where the proportion of ranches in poor condition was greater for poor infrastructure than good or regular infrastructure, and the proportion of ranches in poor condition was greater in years with less precipitation (Table 3).

The range condition distributions were different between ejido and private ranches for 3 of the 4 precipitation categories; they were not different in the $377-409 \mathrm{~mm}$ category (Fig. 2). The proportion of private ranches in poor condition was greater than ejido ranches in the drier years of assessment, the proportion of private ranches in good condition was greater than ejido ranches in the wetter years of assessin regular condition was greater than private ranches in nearly all types of rainfall conditions. 


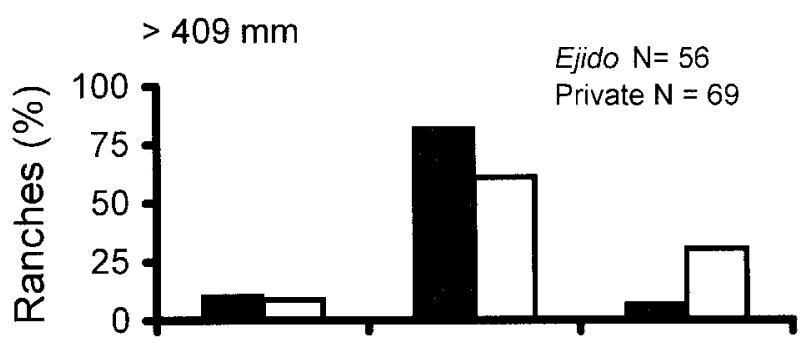

$377-409 \mathrm{~mm}$

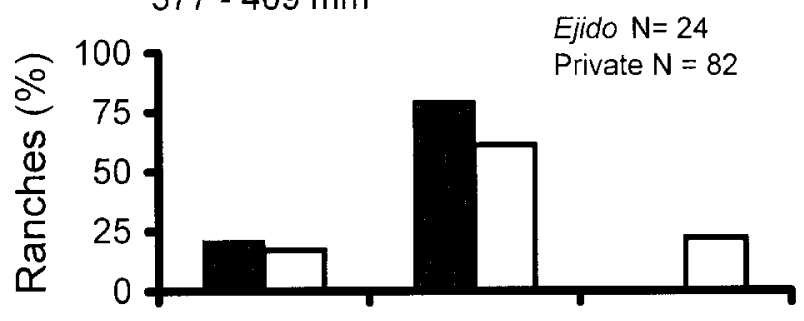

$287-376 \mathrm{~mm}$

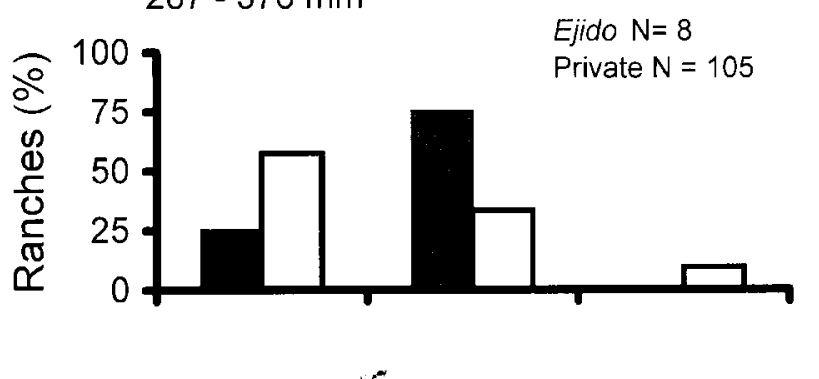

$<287 \mathrm{~mm}$

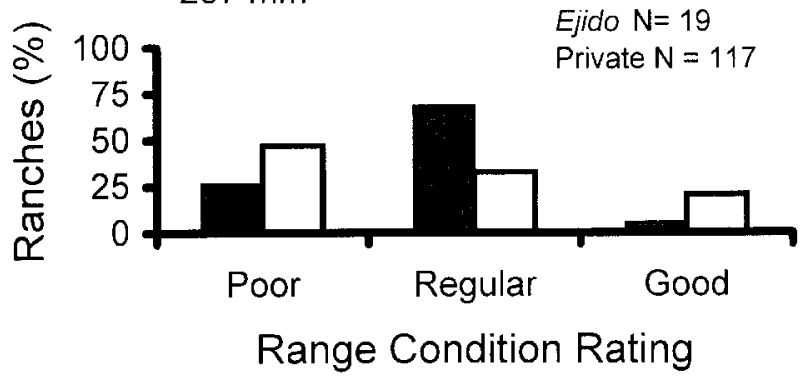

Fig. 2. Comparisons of ejido (solid bar) and private (open bar) ranch distributions of range conditions classes for four levels of precipitation during the year of range condition assessment. Distributions between ejido and private ranches are different $(p<0.05)$ for all levels of precipitation except 287-376 mm $(p=0.06)$.

\section{Discussion}

\section{Management, Tenure System and Range Condition}

For Sonoran ranches assessed by COTECOCA between 1973 to 1993 , we found different levels of management between the tenure systems, but there was little evidence to support the hypothesis that these differences in management were associated with different range conditions between ejido and private tenure systems. All management variables were different between tenure systems when we used the univariate chi-square analysis, but human density and livestock stocking rate were the only management variables significantly related to tenure system in the multivariate ordered logistic regression (note that ranch size was not included in the multivariate analysis because it was dramatically different between tenure systems). We found different distributions of range condition between tenure systems using the univariate chi-square analysis, but tenure was not significantly related to range condition in the logistic regression analysis for all ranches. Infrastructure condition was the only management variable significantly related to range condition in the analysis of all ranches. These results support an interpretation that the management practice of developing infrastructure to improve range conditions transcends these tenure systems. However, one must be cautious, and not place too much emphasis on these multivariate results distinguishing range condition categories because they accounted for only a small, but significant, amount of the variation in range condition.

The differences in ranch size and human density between ejido and private ranches are not surprising because they are inherent in the nature of these systems. Even though the univariate analysis indicated a non-uniform relationship between ranch size and range condition categories, there was no general trend where range condition increased with ranch size, unlike previous findings of a positive relationship between size and condition (e.g. Passmore and Brown 1992, Young 1985). Ranch size was not significantly related to range condition in the logistic regression analysis. The different results between the univariate and multivariate methods may arise from a) size being organized as a continuous and categorical variable in the multivariate and univariate analyses, respectively, and b) less consistency in the relationship between size and condition than for the precipitation and infrastructure variables that were significantly related to range condition.

Generally, the more dense stocking of livestock on ejido than private ranches follows the pattern reported by LaBaume and Dahl (1984) and Yates (1981) in Mexico, and by Ward et al. (1998) in Namibia. However, the differences in stocking rate are not as large for these ranches surveyed in 1973-1993 in Sonora, compared to those in 1960-1970 for other parts of Mexico (LaBaume and Dahl 1984, Yates 1981). Although stocking rate varied among range condition classes in the univariate analysis, it was not included in the multivariate analyses that distinguished the 3 range condition classes. The absence of a significant relationship between range condition and stocking rate in these multivariate analyses is contrary to most expectations (e.g. Hart et al. 1993), but is consistent with the comparison of range condition between communal and private land in Namibia (Ward et al. 1998). Again, these differences between univariate and multivariate results may arise from the same causes as discussed for ranch size. 
The absence of a significant relationship between infrastructure condition and tenure systems in the multivariate analyses is different than the univariate results illustrating a generally better condition of infrastructure on private than ejido ranches. The univariate results are consistent with the differences noted in Mexico by Yates (1981), but the differences between univariate and multivariate results may arise from less consistency in the relationship between infrastructure condition and tenure system than for precipitation, stocking rate, and human density which are significantly related to tenure type. In contrast, infrastructure condition was positively related to range condition in all univariate and multivariate analyses. The generally good condition of infrastructure on these Sonoran ranches is in sharp contrast to Yates' (1981) assessment in the 1970s when two-thirds of all ranches had poor infrastructure conditions.

\section{Bio-physical Characteristics, Tenure System, and Range Condition}

We found no evidence for different levels of rangeland quality between the land tenure systems with either the univariate or multivariate analyses, but there was evidence to support the hypothesis that the relationship between rangeland quality and range condition transcends tenure system. Rangeland quality was significantly related to range condition in the logistic regression analysis for all ranches but it was not significantly related to range condition in the separate analyses for ejido and private ranches. We found evidence that there was a difference in the precipitation received during the year of assessment between the tenure systems, and there was evidence to support the hypothesis that the difference in precipitation between tenure systems was associated with different range conditions between ejido and private ranches. The detailed univariate chi-square analyses describing the relationship between tenure system and range condition at 4 levels of precipitation revealed a stronger relationship between precipitation and range conditions for private ranches than ejido ranches. These results support an interpretation that the relationship between range conditions and rangeland quality transcends these tenure systems, but the relationship between precipitation and range condition does not transcend these tenure systems. However, one must be cautious and not place too much emphasis on these multivariate results distinguishing range condition categories because they accounted for a small, but significant, amount of the variation in range condition.

The positive relationship between rangeland quality and range condition was not consistent with expectations (e.g. Launchbaugh et al. 1990), also, the absence of a tenure related difference in range site is different from patterns in the United States where better sites are often under private ownership (e.g. Starrs 1998).

The relationship between precipitation and rangeland vegetation conditions is inherent in models of vegetation dynamics where transitions from one state of vegetation to another can be more influenced by precipitation amounts and timing than by livestock management (Westoby et al. 1989), and similar patterns can be seen when examining vegetation production in arid regions (Ellis and Swift 1988). A finding that is unique to our study is the greater sensitivity of range condition on private ranches to variation in precipitation than was found on ejido ranches. Our data does not permit an examination of the mechanisms for this intriguing relationship.

\section{Implications}

Our results identify 2 critical issues in management and evaluation of rangelands that apply to all tenure systems: a) encouraging investment in and proper use of infrastructure, and b) developing range condition assessment strategies that are more sensitive to management and less sensitive to precipitation.

The strong relationship between infrastructure condition and range condition, that transcended these 2 tenure systems supports Wilson and Thompson's (1993) proposition that communal properties are as likely to benefit from investment in infrastructure as private ranches. Furthermore, the apparently higher condition of infrastructure in this Sonora sample compared to earlier assessments in Mexico, suggests that ejido ranches have been as likely to invest in infrastructure as private ranches. Finally, these results are consistent with findings suggesting that investment in management transcend the influence of tenure on range condition (Loring and Workman 1987).

The current renaissance in range condition assessment (e.g. Task Force on Unity in Concepts and Terminology 1995, National Research Council 1994, Natural Resource Conservation Service 1997) has focused on parameters and metrics to distinguish management influences from precipitation or other bio-physical influences, and to represent a variety of resource values in addition to livestock forage. While the COTECOCA range condition method can be criticized for adherence to Clementian-based metrics, a more critical area of improvement would be the institution of regular and repeated assessments that would document the trend of conditions. The current COTECOCA data precludes an estimate of the trend in conditions because there was only a one-time assessment for each ranch, and not all ranches were assessed in the same year. The availability of trend information for these Sonoran ranches would have permitted comparisons of ranch performance across the inter-annual variations in weather, rather than the less revealing comparison among ranches assessed in only 1 year. We encourage the measurement of range condition trend on these rangelands to assist in the evaluation of the current privatization opportunity, and to provide criteria for the qualification and assessment of capital assistance programs.

\section{Literature Cited}

Anderson, K.L. and C.L. Fly. 1955. Vegetation-soil relationships in Flint Hills bluestem pastures. J. Range Manage. 8:163-169.

Baden, J. and R. Stroup. 1977. Property rights, environmental quality and the management of national forests. p. 229-240. In: G. Hardin and J. Baden (eds.). Managing the commons, W.H. Freeman and Company, San Francisco, Calif.

Bails, D.G. and L.C. Peppers. 1993. Business fluctuations: forecasting techniques and applications. 2nd ed. Prentice Hall, Englewood Cliffs, N.J.

Comisión Nacional del Agua. 1996. Resumen de precipitaciones del Estado de Sonora. Pamphlet, unpublished data.

Comisión Técnica para la Determinación de Coeficientes de Agostadero. 1974. Coeficientes de Agostadero de la Republica Mexicana: Estado de Sonora. Secretaria de Agricultura y Ganaderia.

Coronado-Quintana, J.A. 1998. Relationship between range condition and the land tenure system in Sonora. Ph.D. Diss., Univ. of Arizona, Tucson, Ariz.

Dyksterhuis, E.J. 1949. Condition and management of rangeland based on quantitative ecology. J. Range Manage. 2:104-115.

Ellis, J.E. and D.M. Swift. 1988. Stability of African pastoral ecosystems: alternate paradigms and implications for development. J. Range Manage. 41:450-459.

Evans, R. A., and R.M. Love. 1957. The step-point method of sampling: A practical tool in range research. J. Range Manage. 10:208-212.

Feeny, D., F. Berkes, B.J. McCay, and J.M. Acheson. 1990. The tragedy of the common: twenty-two years later. Human Ecol. 18:1-19. 
Greene, W. H. 1993. Econometric Analysis. 2nd Ed. Macmillan Publishing Company, New York, N.Y.

Hardin, G. 1968. The tragedy of the commons. Sci. 162:1243-48.

Hart, R. H., S. Clapp, and P. S. Test. 1993. Grazing strategies, stocking rates, and frequency and intensity of grazing on western wheatgrass and blue grama. J. Range Manage. 46:122-126.

Hosmer, D. W. and S. Lemeshow. 1989. Applied Logistic Regression. John Wiley \& Sons, New York, N.Y.

Humphrey, R.R. 1949. Field comments on the range condition method of forage survey. $\mathrm{J}$. Range Manage. 2:1-10.

Instituto Nacional de Estadistica, Geografia y Informatica. 1990. Estadisticas Historicas de Mexico, Tomo 1. INEGI, Aguascalientes, Mexico.

Instituto Nacional de Estadistica, Geografia y Informatica. 1994. Censo Ejidal: Sonora. INEGI, Aguascalientes, Mexico.

Instituto Nacional de Estadistica, Geografia y Informatica. 1997. Anuario Estadistico de Estado de Sonora. INEGI, Aguascalientes, Mexico.

Kohler, H. 1988. Statistics for business and economics. 2ed. Scott, Foreman and Company, Glenview, Ill.

LaBaume, J.T. and B.E. Dahl. 1984. Communal grazing: the case of the Mexican ejido. J. Soil and Water Conserv. 41:24-27.
Launchbaugh, K.L., J.W. Stuth, and J.W. Holloway. 1990. Influence of range site on diet and nutrient intake of cattle. J. Range Manage. 43:109-115.

Loring, M.W. and J.P. Workman. 1987. The relationship between land ownership and range condition in Rich County, Utah. J. Range Manage. 40:290-293.

Menard, S. 1995. Applied logistic regression analysis. Sage Univ. Series of Quantitatitive Appl. in the Social Sciences. Sage Press, Thousand Oaks, Calif.

National Research Council. 1994. Rangeland health: new methods to classify, inventory, and monitor rangelands. Nat. Acad. Press, Washington, D.C.

Natural Resource Conservation Service. 1997. Range and pasture management handbook. U.S. Gov. Printing Office.

Ostrom, E., J. Burger, C.B. Field, R.B. Norgaard, and D. Policansky. 1999. Revisiting the commons: local lessons, global challenges. Sci. 284:278-282.

Passmore, J. G. I. and C. G. Brown. 1992. Property size and rangeland degradation in the Queensland mulga rangelands. Rangeland J. 14(1):9-25.

Smith, J. 1898. Grazing problems in the Southwest and how to meet them. USDA Bull. 16.

Solidaridad. 1992. Nueva Legislación Agraria: Artİculo 27 Constitucional, Ley Agraria, Ley Org.nica de los Tribunales Agrarios. Gaceta de Solidaridad, Mexico, D.F.
Starrs, P.F. 1998. Let the cowboy ride: cattle ranching in the American west. Johns Hopkins Univ. Press, Baltimore, Md.

Task Force on Unity in Concepts and Terminology. 1995. New concepts for assessment of rangeland condition. J. Range Manage. 48:271-282.

Vallentine, J.F. 1990. Grazing management. Academic Press, New York, N.Y.

Ward, D., B.T. Ngairorue, J. Kathena, R. Samuels, and Y. Ofran. 1998. Land degradation is not a necessary outcome of communal pastoralism in arid Namibia. J. Arid Environ. 40:357-371.

Westoby, M., B. Walker and I. Noy Meir. 1989. Opportunistic management for rangelands not at equilibrium. J. Range Manage. 42:266-74.

Wilson, P.N. and G.D. Thompson. 1993. Common property and uncertainty: compensating coalitions by Mexico's pastoral ejidatarios. Econ. Development and Cultural Change 41(2): 299-318.

Worster, D. 1992. Under western skies: nature and history in the American west. Oxford University Press, New York, N.Y.

Yates, L.P. 1981. Mexico's agricultural dilemma. University of Arizona Press, Tucson, Ariz.

Young, M.D. 1985. The influence of farm size on vegetation condition in an arid area. $\mathrm{J}$. Environ. Manage. 21:193-203. 